\title{
Serum Levels of Immunoglobulins in Marasmic Infants
}

\author{
SAMIR S. NAJJAR, MONA STEPHAN, and RAJA Y. ASFOUR \\ From the Department of Pediatrics, School of Medicine, American University of Beirut, Lebanon
}

The syndrome of protein-calorie malnutrition is associated with an increased frequency of infections which often precipitate or aggravate the state of malnutrition. The importance and the farreaching implications of the interaction between malnutrition and infections, a predominantly synergistic one, have been stressed by Scrimshaw, Taylor, and Gordon (1959) and more recently by the Joint FAO/WHO Expert Committee on Nutrition (1967).

Of the various mechanisms of the host's defences against infection, antibody production assumes an important but not an exclusive role. Antibody response in human malnutrition has been studied in the kwashiorkor type of malnutrition and in adults with severe protein depletion. No such studies have been reported in marasmic malnutrition, the much more prevalent type of human malnutrition (McLaren, 1966).

Infants with kwashiorkor were able to produce antibodies against typhoid, poliomyelitis, and smallpox vaccines (Pretorius and De Villiers, 1962; Brown and Katz, 1965) and had normal levels of isohaemagglutinins (Kahn, Stein, and Zontendyk, 1957). Young adults with severe protein deficiency responded adequately to diphtheria toxoid (Balch, 1950; Havens, Bock, and Siegel, 1954).

To our knowledge, only one study has been published reporting on the levels of immunoglobulins in kwashiorkor (Brown and Katz, 1965). The authors found a significant decrease in the levels of IgG immunoglobulins in the sera of 20 children with kwashiorkor as compared with 5 normal children. The serum levels of $\operatorname{IgM}$ and IgA were not statistically different from those of the normal children.

The purpose of this communication is to report the levels of the serum immunoglobulins in infants with marasmic malnutrition.

Received August 9, 1968.

\section{Subjects and Methods}

Studies were made of 16 marasmic infants between the ages of 3 and $\mathbf{3 0}$ months. The cause of malnutrition in all 16 was primarily undernutrition aggravated in most instances by gastro-intestinal disturbances or respiratory infections. None had the clinical changes of kwashiorkor and none had a primary disease besides malnutrition. The age, sex, weight, albumin, and globulin levels are shown in Table I. The serum protein, albumin, and globulin were determined by the method of Wolfson et al. (1948).

Serum levels of $\operatorname{IgM}, \operatorname{IgA}$, and $\operatorname{IgG}$ were determined by the radial immunodiffusion method of Mancini, Carbonara, and Heremans (1965), using commercially available antibody agar plates (Immunoplates, Hyland Laboratories, Los Angeles, California). Different dilutions of pooled normal serum previously standardized against immunochemically pure human immunoglobulins were used as standards; these were supplied by Hyland Laboratories. Each serum was tested on at least two different occasions for each of the three immunoglobulins, and the values were averaged.

The serum immunoglobulin levels of 23 healthy infants of the same population and of the same age-group were determined in a similar fashion.

\section{Results}

Because of the known variability of the immunoglobulin levels with age, the marasmic and the healthy control infants were divided into 3 groups: 3 to 6 months, 7 to 12 months, and 13 to 30 months. The serum levels of the immunoglobulins in the various age-groups are shown in Tables II, III, and IV and are plotted in Fig. 1-3.

In the 3 to 6 months group, the mean serum levels of $\operatorname{IgM}, \operatorname{IgA}$, and $\operatorname{IgG}$ in the marasmic infants were much higher than the respective mean levels for healthy infants. This difference was statistically significant.

In the 7 to 12 months group, the levels of IgA and IgG were similar in the marasmic and the healthy infants; the IgM levels were higher in the 
TABLE I

Age, Weight, and Serum Proteins of Marasmic Infants

\begin{tabular}{|c|c|c|c|c|c|c|}
\hline Case No. & Sex & Age (mth.) & Weight (g.) & $\begin{array}{c}\text { Serum Protein } \\
\quad(\mathrm{g} . / 100 \mathrm{ml} .)\end{array}$ & Albumin (g. $/ 100 \mathrm{ml})$. & Globulin (g. $/ 100 \mathrm{ml}$. ) \\
\hline 1 & $\mathbf{M}$ & 3 & 2860 & $5 \cdot 78$ & $3 \cdot 12$ & $2 \cdot 66$ \\
\hline 2 & $M$ & $4 \frac{1}{2}$ & 4350 & $5 \cdot 88$ & $3 \cdot 64$ & $2 \cdot 24$ \\
\hline 3 & $\mathbf{M}$ & $4 \frac{1}{2}$ & 3200 & $7 \cdot 20$ & - & 一 \\
\hline 4 & $M$ & 5 & 3800 & $3 \cdot 30$ & $1 \cdot 5$ & $1 \cdot 8$ \\
\hline 5 & $\mathrm{~F}$ & 5 & 2745 & $6 \cdot 25$ & $4 \cdot 0$ & $2 \cdot 25$ \\
\hline 6 & $\mathrm{~F}$ & 5 & 3930 & $5 \cdot 90$ & - & - \\
\hline 7 & $\mathrm{M}$ & $5 \frac{1}{2}$ & 3880 & $6 \cdot 50$ & - & - \\
\hline 8 & $\mathrm{~F}$ & 7 & 3700 & $7 \cdot 46$ & $4 \cdot 80$ & $2 \cdot 66$ \\
\hline 9 & M & 8 & 6800 & - & - & - \\
\hline 10 & $\mathbf{F}$ & 9 & 4200 & $6 \cdot 89$ & $3 \cdot 83$ & $3 \cdot 06$ \\
\hline 11 & $\mathbf{M}$ & 9 & 4570 & $8 \cdot 06$ & $4 \cdot 44$ & $3 \cdot 62$ \\
\hline 12 & $\mathbf{M}$ & 10 & 4900 & $6 \cdot 62$ & $4 \cdot 41$ & $2 \cdot 21$ \\
\hline 13 & F & 10 & 4170 & $5 \cdot 03$ & $2 \cdot 45$ & $2 \cdot 58$ \\
\hline 14 & $\mathrm{M}$ & 15 & 4600 & $7 \cdot 68$ & $3 \cdot 57$ & $4 \cdot 11$ \\
\hline 15 & $\mathrm{~F}$ & 15 & 5500 & $6 \cdot 00$ & $4 \cdot 0$ & $\overline{\mathbf{z}} \cdot \overline{\mathrm{u}}$ \\
\hline 16 & $M$ & 30 & 6400 & $4 \cdot 80$ & $2 \cdot 2$ & $2 \cdot 6$ \\
\hline
\end{tabular}

marasmic group and the difference was statistically significant.

In the 13 to 30 months group, there were only 3 marasmic infants, and IgM and IgG levels in these 3 were comparable to those of the healthy controls. IgA, however, was excessively raised in the 3 marasmic infants; 430, 300, and 215 $\mathrm{mg} . / 100 \mathrm{ml}$., respectively, as compared to a mean of $50 \mathrm{mg} . / 100 \mathrm{ml}$. in the control group, with a range of 28 to $73 \mathrm{mg} . / 100 \mathrm{ml}$.

\section{Discussion}

Marasmic infants seem capable of producing normal or above normal amounts of immunoglobulins when compared to healthy infants of the same age. The increased serum levels of the $\operatorname{IgM}$

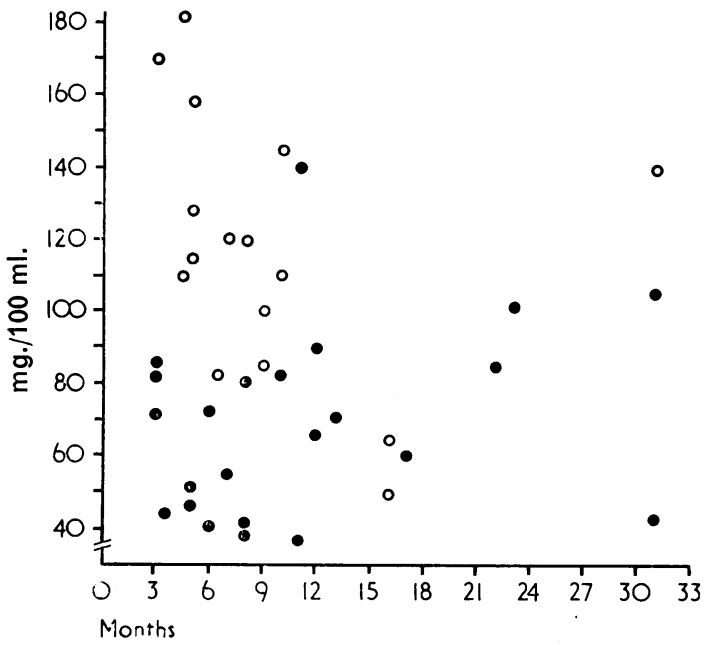

FIG. 1.-Serum levels of IgM. - Healthy infants; $C$ marasmic infants.

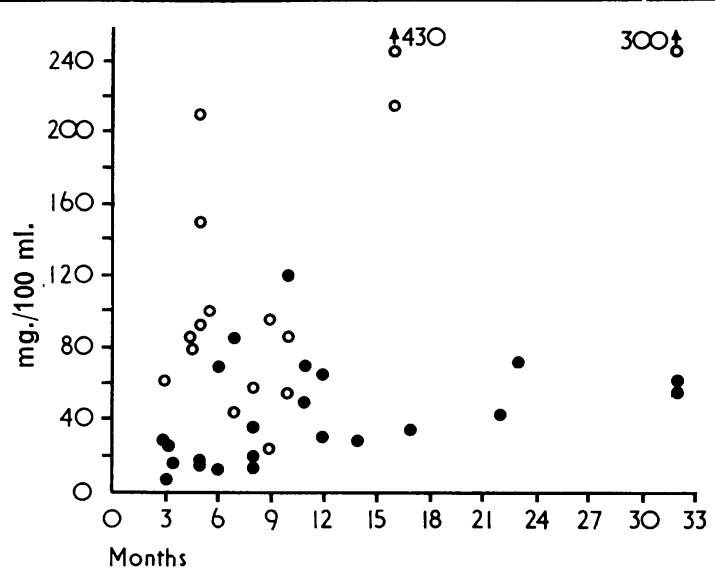

Fig. 2.-Serum levels of $\operatorname{Ig} A$.

Healthy infants;

○ marasmic infants.

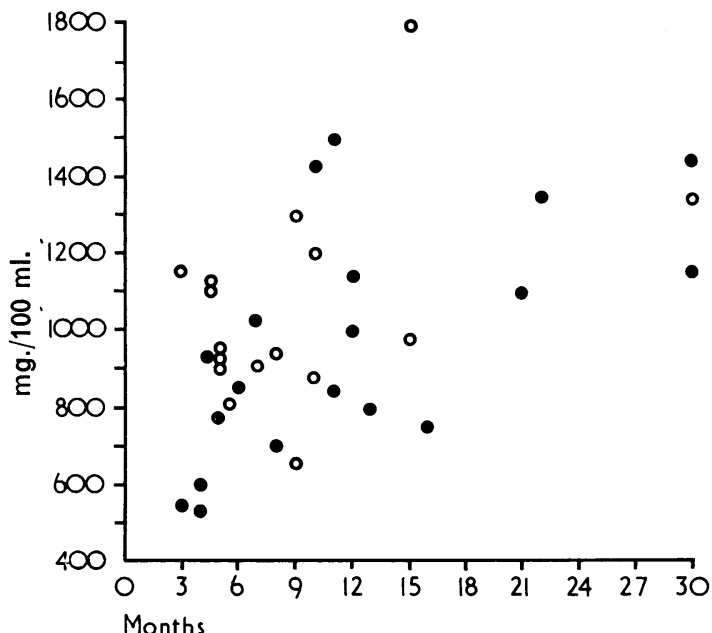

FIG. 3.-Serum levels of IgG. - Healthy infants; $\mathrm{O}$ marasmic infants. 
TABLE II

Levels of Serum Immunoglobulins in

Marasmic and Control Infants 3 to 6 Months of Age

\begin{tabular}{|c|c|c|c|c|}
\hline $\begin{array}{l}\text { Case } \\
\text { No. }\end{array}$ & Age (mth.) & $\begin{array}{c}\text { IgM } \\
(\mathrm{mg} \cdot / \\
100 \mathrm{ml} .)\end{array}$ & $\begin{array}{c}\text { IgA } \\
(\mathrm{mg} \cdot ! \\
100 \mathrm{ml} .)\end{array}$ & $\begin{array}{c}\mathrm{IgG} \\
(\mathrm{mg} . / \\
100 \mathrm{ml} .)\end{array}$ \\
\hline $\begin{array}{l}1 \\
2 \\
3 \\
4 \\
5 \\
6 \\
7\end{array}$ & $\begin{array}{l}3 \\
4 \frac{1}{2} \\
4 \frac{1}{2} \\
5 \\
5 \\
5 \\
5 \frac{1}{2}\end{array}$ & $\begin{array}{r}170 \\
182 \\
110 \\
115 \\
128 \\
158 \\
82\end{array}$ & $\begin{array}{r}62 \\
79 \\
85 \\
210 \\
150 \\
92 \\
100\end{array}$ & $\begin{array}{r}1150 \\
1125 \\
1100 \\
950 \\
900 \\
930 \\
800\end{array}$ \\
\hline \multicolumn{2}{|c|}{$\begin{array}{l}\text { Mean } \\
\text { Standard deviation } \\
\text { Standard error of mean }\end{array}$} & $\begin{array}{l}149 \cdot 3^{\star} \\
31 \cdot 1 \\
11 \cdot 74\end{array}$ & $\begin{array}{l}111 \cdot 2^{\star} \\
51 \cdot 5 \\
19 \cdot 4\end{array}$ & $\begin{array}{c}993 \cdot 5 \dagger \\
132 \cdot 4 \\
50 \cdot 0\end{array}$ \\
\hline $\begin{array}{l}\quad \text { Contr } \\
\text { Mean } \\
\text { Standar } \\
\text { Standar }\end{array}$ & $\begin{array}{l}\text { (8 normal } \\
\text { ants) } \\
\text { eviation } \\
\text { rror of mean }\end{array}$ & $\begin{array}{l}61 \cdot 6^{\star} \\
18 \cdot 4 \\
6 \cdot 5\end{array}$ & $\begin{array}{l}24 \cdot 6^{\star} \\
19 \cdot 5 \\
6 \cdot 9\end{array}$ & $\begin{array}{l}680 \dagger \\
170 \\
69 \cdot 8\end{array}$ \\
\hline
\end{tabular}

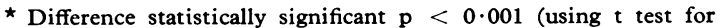
small samples).

$\dagger$ Difference statistically significant $p<0.01$ (using $t$ test for small samples).

TABLE IV

Levels of Serum Immunoglobulins in Marasmic and Control Infants, 13 to 30 Months of Age

\begin{tabular}{l|c|c|c|c}
\hline \begin{tabular}{l|l|l|} 
Case \\
No.
\end{tabular} & Age (mth.) & $\begin{array}{c}\text { IgM (mg./ } \\
100 \mathrm{ml} .)\end{array}$ & $\begin{array}{c}\text { IgA (mg./ } \\
100 \mathrm{ml} .)\end{array}$ & $\begin{array}{c}\text { IgG (mg./ } \\
100 \mathrm{ml} .)\end{array}$ \\
\hline 14 & 15 & 64 & 430 & 1800 \\
15 & 15 & 49 & 215 & 970 \\
16 & 30 & 140 & 300 & 1350 \\
\hline \multicolumn{2}{l|}{$\begin{array}{l}\text { Controls (6 normal } \\
\text { infants) }\end{array}$} & & & \\
Mean & $77 \cdot 3$ & 50 & 1100 \\
Standard deviation & $24 \cdot 1$ & $17 \cdot 5$ & $285 \cdot 4$ \\
Range & $43-105$ & $28-73$ & $750-1450$ \\
& & & \\
\hline
\end{tabular}

and IgG in the 3 to 6 months group probably do not represent a haemoconcentration, because blood was drawn in most instances several days after the initial period of hydration, and because of the disproportionate rise in the 3 immunoglobulins in the same subject. More probably, this rise represents the response to the recurrent infections to which they have been subjected. The same can be said about the increased levels of $\operatorname{IgM}$ in the 7 to 12 months group. It is interesting to note the marked rise in the serum levels of $\operatorname{IgA}$ in the 3 older marasmic infants and in the marasmic infants 3 to 6 months of age. The significance of this rise is difficult to interpret. IgA is the major immuno-
TABLE III

Levels of Serum Immunoglobulins in

Marasmic and Control Infants 7 to 12 Months of Age

\begin{tabular}{|c|c|c|c|c|}
\hline $\begin{array}{l}\text { Case } \\
\text { No. }\end{array}$ & Age (mth.) & $\begin{array}{c}\text { IgM (mg./ } \\
100 \mathrm{ml} .)\end{array}$ & $\begin{array}{l}\text { IgA (mg./ } \\
100 \mathrm{ml} .)\end{array}$ & $\begin{array}{l}\text { IgG (mg./ } \\
100 \mathrm{ml} .)\end{array}$ \\
\hline $\begin{array}{r}8 \\
9 \\
10 \\
11 \\
12 \\
13\end{array}$ & $\begin{array}{r}7 \\
8 \\
9 \\
9 \\
10 \\
10\end{array}$ & $\begin{array}{r}120 \\
120 \\
85 \\
100 \\
110 \\
145\end{array}$ & $\begin{array}{l}44 \\
57 \\
96 \\
24 \\
86 \\
55\end{array}$ & $\begin{array}{r}900 \\
940 \\
650 \\
1300 \\
1200 \\
870\end{array}$ \\
\hline \multicolumn{2}{|c|}{$\begin{array}{l}\text { Mean } \\
\text { Standard deviation } \\
\text { Standard error of } \\
\text { mean }\end{array}$} & $\begin{array}{c}113 \cdot 3^{\star} \\
20 \cdot 4 \\
8 \cdot 3\end{array}$ & $\begin{array}{l}60 \cdot 3 \ddagger \\
22 \cdot 7 \\
10 \cdot 8\end{array}$ & $\begin{array}{l}976 \cdot 6 \ddagger \\
236 \\
96 \cdot 5\end{array}$ \\
\hline \multicolumn{2}{|c|}{$\begin{array}{l}\text { Mean } \\
\text { Standard deviation } \\
\text { Standard error of } \\
\text { mean }\end{array}$} & $\begin{array}{l}69 \cdot 8^{\star} \\
33 \cdot 0 \\
11 \cdot 0\end{array}$ & $\begin{array}{l}54 \cdot 1 \neq \\
37 \cdot 7 \\
11 \cdot 6\end{array}$ & $\begin{array}{c}1090 \cdot 7 \ddagger \\
293 \cdot 4 \\
110 \cdot 9\end{array}$ \\
\hline
\end{tabular}

$\star$ Difference statistically significant $p<0.02$ (using $t$ test for small samples).

$\ddagger D$ ifference statistically not significant $p>0.05$ (using $t$ test for small samples).

globulin found in the epithelium of the gastrointestinal tract (Gelzayd, Kraft, and Fitch, 1967). One may speculate that increased IgA in the serum may reflect the recurrent gastro-intestinal disorders from which these children had suffered.

\section{Summary}

The serum levels of IgM, IgA, and IgG were determined in 16 infants with marasmic malnutrition. The levels of these 3 immunoglobulins were significantly higher than those of well-nourished infants 3 to 6 months of age. In the older marasmic infants the levels af IgM in those between 7 and 12 months and of $\operatorname{IgA}$ in those between 13 and 30 months were significantly higher than the corresponding levels in the well-nourished infants.

\section{REFERENCES}

Balch, H. H. (1950). Relation of nutritional deficiency in man to antibody production. $\mathcal{F}$. Immunol., 64, 397.

Brown, R. E., and Katz, M. (1965). Antigenic stimulation in undernourished children. East Afr. med. F., 42, 221.

Gelzayd, E. A., Kraft, S. C., and Fitch, F. W. (1967). Immunoglobulin A: localization in rectal mucosal epithelial cells. Science, 157, 930.

Havens, W. P., Jr., Bock, D. G., and Siegel, I. (1954). Capacity of seriously wounded patients to produce antibody. f. clin. Invest., 33, 940.

Joint FAO/WHO Expert Committee on Nutrition (1967). Seventh Report. Wld Hlth Org. techn. Rep. Ser., No. 377.

Kahn, E., Stein, H., and Zontendyk, A. (1957). Isohemagglutinins and immunity in malnutrition. Amer. F. clin. Nutr., 5, 70. 
Mancini, G., Carbonara, A. O., and Heremans, J. F. (1965). Immunochemical quantitation of antigens by single radial immunodiffusion. Immunochemistry, 2, 235.

McLaren, D. S. (1966). A fresh look at protein-calorie malnutrition. Lancet, 2, 485.

Pretorius, P. J., and De Villiers, L. S. (1962). Antibody response in children with protein malnutrition. Amer. f. clin. Nutr., $10,379$.
Scrimshaw, N. S., Taylor, C. E., and Gordon, J. E. (1959). Interactions of nutrition and infection. Amer. F. med. Sci., 237, 367.

Wolfson, W. Q., Cohn, C., Calvary, E., and Ichiba, F. (1948). Studies in serum proteins. V. A rapid procedure for the estimation of total protein, true albumin, total globulin, alpha globulin, beta globulin and gamma globulin in $1.0 \mathrm{ml}$. of serum. Amer. F. clin. Path., 18, 723.

The following articles will appear in future issues of this Journal:

Hyperammonaemia: a Variant Type of Deficiency of Liver Ornithine Transcarbamylase. By B. Levin, R. H. Dobbs, E. Ann Burgess, and T. Palmer.

Hyperammonaemia : a Deficiency of Liver Ornithine Transcarbamylase. Occurrence in Mother and Child. By B. Levin, J. M. Abraham, V. G. Oberholzer, and E. Ann Burgess.

Adrenal Response to ACTH in Patients with Prader-Willi Syndrome, Simple Obesity and Constitutional Dwarfism. By B. T. Rudd, G. W. Chance, and C. G. Theodoridis.

Low Birthweight Dwarfism with Asymmetry (Silver's Syndrome): Treatment with Human Growth Hormone. By J. M. Tanner and T. J. Ham.

Sotos' Syndrome of Cerebral Gigantism. By J. M. Abraham and G. J. A. I. Snodgrass.

Simplified Nail Clipping Test for the Diagnosis of Cystic Fibrosis. By M. Antonelli, G. Ballati, and L. Annibaldi.

Use of Medium-chain Triglyceride Diets in Children with Malabsorption. By F. C. Leyland, Audrey S. Fosbrooke, June K. Lloyd, M. M. Segall, I. Tamir, R. Tomkins, and O. H. Wolff.

Serum and Adipose Tissue Lipids in Children Receiving Medium-chain Triglyceride Diets. By I. Tamir, Susan Gould, Audrey S. Fosbrooke, and June K. Lloyd.

An Infantile Case of Subacute Sclerosing Panencephalitis with an Abnormal Ganglioside Pattern in the Brain. By A. D. Dayan and J. N. Cumings.

Graves's Disease, an Unusual Complication: Raised Intracranial Pressure due to Premature Fusion of Skull Sutures. By D. C. Robinson, R. Hall, and D. S. Munro.

Hypoglycaemia Complicating Haemolytic Disease of the Newborn. By H. V. Price.

Sphingomyelin of Red Blood Cells in Lipidosis and in Dementia of Unknown Origin in Children. By C. J. M. Hooghwinkel, H. H. van Gelderen, and A. Staal.

Hyperammonaemia due to Ornithine Transcarbamylase Deficiency. By Ian J. Hopkins, John F. Connelly, A. G. Dawson, F. J. R. Hird, and T. G. Maddison.

Intelligence and the Gene for Duchenne Muscular Dystrophy. By E. J. Prosser, E. G. Murphy, and M. W. Thompson.

Peritoneal Dialysis in Reduction of Blood Ammonia. Levels in a Case of Hyperammonaemia. By J. T. Herrin and D. A. McCredie.

Care and Observation of a Germ-free Neonate. By R. D. Barnes, A. Bentovim, Shirley Hensman, and Alina R. Piesowicz. 